\title{
Antagonism of $\mathrm{P}_{2} \mathrm{Y}_{1}$-induced vasorelaxation by acyl CoA: a critical role for palmitate and 3 '-phosphate
}

\author{
E Alefishat*, SPH Alexander and V Ralevic \\ Cardiovascular Research Group and Lipid Signalling, School of Biomedical Sciences, University of \\ Nottingham, Nottingham, UK
}

Correspondence

Vera Ralevic, School of Biomedical Sciences, University of Nottingham, Nottingham NG7 2UH, UK. E-mail: vera.ralevic@nottingham.ac.uk

*Present address: Department of Biopharmaceutics and Clinical Pharmacy, Faculty of Pharmacy, University of Jordan, Amman 11942, Jordan.

\section{Keywords}

$\mathrm{P} 2 \mathrm{Y}$ receptors; CoA; acetyl CoA; palmitoyl CoA; rat thoracic aorta; porcine mesenteric artery; porcine coronary artery; vasorelaxation

\section{Received}

13 September 2012

Revised

26 November 2012

Accepted

27 November 2012

\section{BACKGROUND AND PURPOSE}

Acyl derivatives of CoA have been shown to act as antagonists at human platelet and recombinant P2Y, receptors, but little is known about their effects in the cardiovascular system. This study evaluated the effect of these endogenous nucleotide derivatives at $P 2 Y_{1}$ receptors natively expressed in rat and porcine blood vessels.

\section{EXPERIMENTAL APPROACH}

Isometric tension recordings were used to evaluate the effects of $\mathrm{COA}$, acetyl $\mathrm{CoA}$, palmitoyl $\mathrm{CoA}(\mathrm{PaCoA})$ and 3'-dephospho-palmitoyl-CoA on concentration relaxation-response curves to ADP and uridine triphosphate (UTP). A FlexStation monitored ADP- and UTP-evoked calcium responses in HEK293 cells.

\section{KEY RESULTS}

Acetyl $\mathrm{CoA}$ and $\mathrm{PaCoA}$, but not CoA, inhibited endothelium-dependent relaxations to ADP with apparent selectivity for

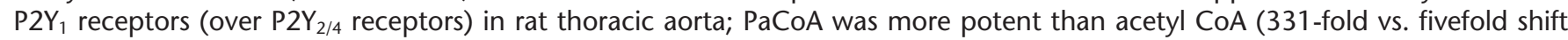
of $\mathrm{ADP}$ response curve evoked by $10 \mu \mathrm{M} \mathrm{PaCoA}$ and acetyl $\mathrm{CoA}$, respectively); the apparent $\mathrm{pA}_{2}$ value for PaCoA was 6.44. 3'-dephospho-palmitoyl-CoA $(10 \mu \mathrm{M})$ was significantly less potent than PaCoA (20-fold shift). In porcine mesenteric arteries, $\mathrm{PaCOA}$ and the P2Y receptor antagonist MRS2500 blocked ADP-mediated endothelium-dependent relaxations; in contrast, they were ineffective against ADP-mediated endothelium-independent relaxation in porcine coronary arteries (which does not involve P2Y 1 receptors). Calcium responses evoked by ADP activation of endogenous P2Y, receptors in HEK293 cells were inhibited in the presence of PaCoA, which failed to alter responses to UTP (acting at endogenous P2Y $2 / 4$ receptors).

\section{CONCLUSIONS AND IMPLICATIONS}

Acyl derivatives of $\mathrm{COA}$ can act as endogenous selective antagonists of $\mathrm{P} 2 \mathrm{Y}_{1}$ receptors in blood vessels, and this inhibitory effect critically depends on the palmitate and 3'-ribose phosphate substituents on CoA.

\section{Abbreviations}

EMEM, Eagle's minimum essential medium; FCS, fetal calf serum; PaCoA, palmitoyl CoA

\section{Introduction}

The structural similarity between the endogenous $\mathrm{P}_{2} \mathrm{Y}_{1}$ receptor ligand ADP and CoA prompted Coddou et al. (2003) to investigate the effect of CoA and its derivatives as antagonists at human recombinant $\mathrm{P}_{2} \mathrm{Y}_{1}$ receptors expressed in Xenopus laevis oocytes (Coddou et al., 2003) (see Figure 1 for structures). They found that PaCoA and the hypolipidemic drug metabolites of CoA, nafenopin-CoA and ciprofibroyl-CoA, were antagonists of chloride currents mediated by ATP via 


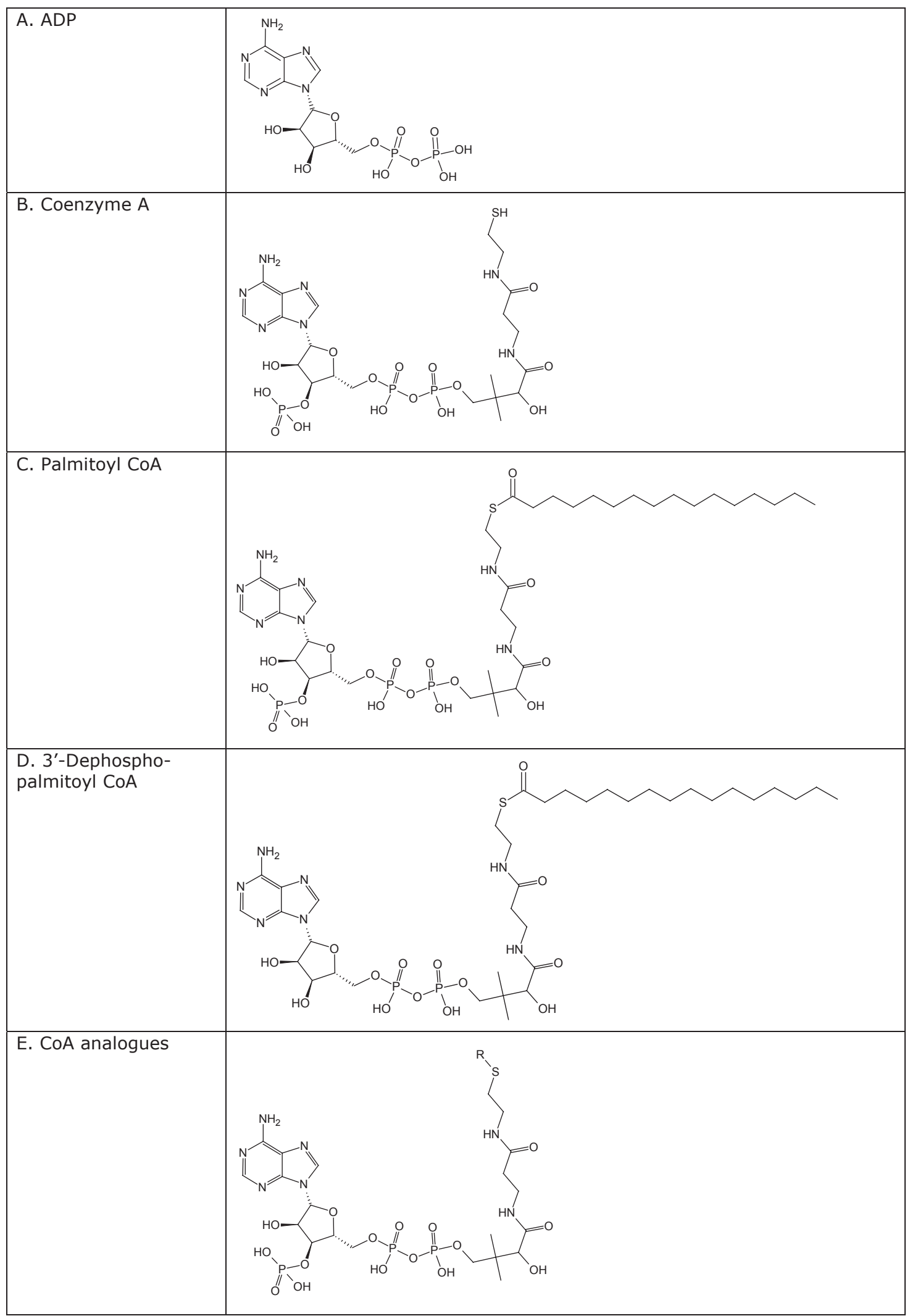

Figure 1

Structures of (A) ADP, (B) CoA, (C) palmitoyl CoA, (D) 3'-dephospho-palmitoyl CoA and (E) CoA analogues (substitutions at ' $R$ ') (for example, in acetyl $\mathrm{CoA}$ the acetyl group $\left(\mathrm{CH}_{3} \mathrm{C}=\mathrm{O}\right)$ is attached to the sulphur through a thiol ester type bond). Note the similarity between the compounds with regard to their adenine, ribose and diphosphate moieties. $3^{\prime}$-dephospho-PaCoA differs from PaCoA in that it lacks a $3^{\prime}$-ribose phosphate. 
actions at $\mathrm{P}_{2} \mathrm{Y}_{1}$ receptors; $\mathrm{CoA}$ and acetyl $\mathrm{CoA}$ were found to be less effective than the other compounds tested. There was no significant antagonism by CoA or ciprofibroyl-CoA of $\mathrm{P}_{2} \mathrm{Y}_{2}$, $\mathrm{P}_{2} \mathrm{X}_{2}, \mathrm{P}_{2} \mathrm{X}_{4}$ and $5 \mathrm{HT}_{2 \mathrm{~A} / \mathrm{C}}$ receptors (Coddou et al., 2003). A later study investigated the effect of acyl derivatives of CoA at endogenous $\mathrm{P}_{2} \mathrm{Y}_{1}$ and $\mathrm{P} 2 \mathrm{Y}_{12}$ receptors on platelets and concluded that $\mathrm{PaCoA}$ is an antagonist mainly at $\mathrm{P}_{2} \mathrm{Y}_{1}$, but also at $\mathrm{P}_{2} \mathrm{Y}_{12}$ receptors and that it may function as an endogenous modulator of platelet function (Manolopoulos et al., 2008). The effect of side chain length and saturation on the potency of acyl-CoA derivatives has been studied and it has been shown that increasing the acyl-CoA side chain length and degree of saturation increases the potency of these compounds at receptors or ion channels (Coddou et al., 2003; Riedel and Light, 2005; Manolopoulos et al., 2008). The effect of acyl derivatives of CoA at endogenous $\mathrm{P}_{2} \mathrm{Y}_{1}$ receptors in blood vessels and at endogenous $\mathrm{P}_{2} \mathrm{Y}_{1}$ receptors in human cell lines is unknown.

The present study investigated, using rat thoracic aorta, porcine mesenteric artery, porcine coronary artery and HEK 293 cells, whether responses mediated by ADP through the $\mathrm{P}_{2} \mathrm{Y}_{1}$ receptor can be blocked by CoA, acetyl CoA or PaCoA (Figure 1). It has previously been shown that the rat thoracic aorta expresses on its endothelium $\mathrm{P}_{2} \mathrm{Y}_{1}$ receptors and uridine triphosphate (UTP)-sensitive receptors, which could be $\mathrm{P}_{2} \mathrm{Y}_{2}$ or $\mathrm{P}_{2} \mathrm{Y}_{4}$ receptors (Rose'Meyer and Hope, 1990; Hansmann et al., 1997; Dol-Gleizes et al., 1999). In a preliminary report, we identified the expression of $\mathrm{P}_{2} \mathrm{Y}_{1}$ receptors on the endothelium of the porcine mesenteric artery (Alefishat et al., 2010), in line with the expression of $\mathrm{P}_{2} \mathrm{Y}_{1}$ receptors on the endothelium of rat and mouse mesenteric arteries (Bultmann et al., 1998; Buvinic et al., 2002; Harrington et al., 2007). Indeed, in the majority of blood vessels, vasorelaxant P2 $\mathrm{Y}_{1}$ (and $\mathrm{P} 2 \mathrm{Y}_{2 / 4 / 6}$ ) receptors are expressed on the endothelium (Ralevic and Burnstock, 1998). In contrast, coronary arteries of a variety of species, including human, lamb, rabbit and guinea pig express vasorelaxant $\mathrm{P} 2 \mathrm{Y}$ receptors (of a subtype yet to be defined) on the smooth muscle (Keef et al., 1992; Corr and Burnstock, 1994; Saetrum Opgaard and Edvinsson, 1997; Simonsen et al., 1997). HEK293 cells express $\mathrm{P}_{2} \mathrm{Y}_{1}, \mathrm{P}_{2} \mathrm{Y}_{2}$ and $\mathrm{P} 2 \mathrm{Y}_{4}$ receptors endogenously, which can be activated by ADP, UTP and ATP to induce an increase in $\left[\mathrm{Ca}^{2+}\right]_{\mathrm{i}}$ (Schachter et al., 1997; Bultmann et al., 1998; Fischer et al., 2005). At the $\mathrm{P}_{2} \mathrm{Y}_{1}$ receptor, ADP is a more potent agonist than ATP, while ATP and UTP have equal potency as agonists at $\mathrm{P}_{2} \mathrm{Y}_{2}$ receptors; UTP is a more potent agonist at $\mathrm{P}_{2} \mathrm{Y}_{4}$ receptors than ATP, but can also act at $\mathrm{P}_{2} \mathrm{Y}_{6}$ receptors following breakdown to UDP (Ralevic and Burnstock, 1998; Guns et al., 2006; Bar et al., 2008).

Acyl-CoAs are essential intermediates in lipid biosynthesis and fatty acid metabolism. The possibility that acyl-CoAs play a significant role as endogenous modulators of a number of transport and enzyme systems, and more recently of $\mathrm{P}_{2} \mathrm{Y}_{1}$ receptor signalling, has received increasing attention (Harris et al., 1972; Lerner et al., 1972; Tippett and Neet, 1982; Agius et al., 1987; Li et al., 1990; Boylan and Hamilton, 1992; Hertz et al., 1998; Coddou et al., 2003; Manolopoulos et al., 2008). Normally, intracellular acyl-CoAs are kept at low levels by acyl CoA-binding proteins and fatty acid-binding proteins (Knudsen et al., 2000; Schroeder et al., 2008). However, they may be released during certain conditions such as heart ischaemia, endurance training, diabetes and acute ischaemic stroke (van Breda et al., 1992; Pelsers et al., 1999; Sambandam and Lopaschuk, 2003; Wunderlich et al., 2005); in these states, high levels of extracellular acyl-CoA derivatives may accumulate.

The present study showed that endogenous nucleotide derivatives, namely acetyl $\mathrm{CoA}$ and $\mathrm{PaCoA}$, are antagonists of responses at $\mathrm{P}_{2} \mathrm{Y}_{1}$ receptors in rat thoracic aorta, porcine mesenteric artery and HEK293 cells. The selectivity of these compounds for $\mathrm{P}_{2} \mathrm{Y}_{1}$ receptors over co-expressed $\mathrm{P}_{2} \mathrm{Y}_{2 / 4 / 6}$ receptors was also demonstrated. Moreover, we have shown that this inhibitory effect critically depends on the presence of the 3'-ribose phosphate on the CoA group as well as the palmitate. These results raise the possibility of a novel endogenous selective regulation of $\mathrm{P} 2$ receptor signalling involving inhibition of $\mathrm{P}_{2} \mathrm{Y}_{1}$ receptors via CoA compounds.

\section{Materials and methods}

\section{Isometric tension recordings of rat thoracic aorta}

Male Wistar rats (200-280 g), obtained from Charles River (England, UK), were used in this study. After stunning, they were killed by cervical dislocation. Segments of rat thoracic aorta were mounted for isometric tension recordings in oxygenated Krebs-Henseleit solution (composition mmol $\mathrm{L}^{-1}$ : $\mathrm{NaCl}$ 118.4, $\mathrm{KCl}$ 4.7, $\mathrm{MgSO}_{4}$ 1.25, $\mathrm{CaCl}_{2}$ 1.2, $\mathrm{NaHCO}_{3} 24.9$, $\mathrm{KH}_{2} \mathrm{PO}_{4} 1.2$, glucose 11.1) as described previously (Bultmann et al., 1998). Tissue viability was assessed by eliciting contractions with $60 \mathrm{mM} \mathrm{KCl}$. The rings were preconstricted with methoxamine to a tension of $50-75 \%$ of the $\mathrm{KCl}$ contraction. Concentration-relaxation response curves were then constructed to increasing cumulative concentrations of ADP or UTP, $\mathrm{P}_{2} \mathrm{Y}_{1^{-}}$and $\mathrm{P}_{2} \mathrm{Y}_{2 / 4}$-selective agonists, respectively. In separate experiments to investigate the possible antagonistic effect of acyl-CoA derivatives (CoA, acetyl CoA, PaCoA or 3'-dephospho-PaCoA), these compounds were added $10 \mathrm{~min}$ before methoxamine addition. Time control experiments were performed using the same protocol; after contracting vessels with methoxamine they were left for $1 \mathrm{~h}$ to check for any loss of tone. To check for any direct effect of PaCoA, $10 \mu \mathrm{M}$ was added after contracting the vessels with methoxamine and left for $1 \mathrm{~h}$. Blood vessel tension was measured every $6 \mathrm{~min}$. In some vessels, endothelium removal was achieved by rubbing the lumen gently with forceps, and acetylcholine (100 nM) was used to assess successful removal of the endothelium.

\section{Isometric tension recordings of porcine mesenteric and coronary arteries}

Porcine mesenteries and hearts, from breeds of the modern hybrid pig, of either sex, were obtained from a local abattoir (Wood and Sons Abattoir, Clipstone, Mansfield, Nottinghamshire, England), and delivered to the lab on ice. Segments of porcine mesenteric and coronary arteries were dissected out and stored overnight at $4^{\circ} \mathrm{C}$ in oxygenated Krebs-Henseleit solution. The following morning, connective tissue was removed and the vessels were cut into segments $3-4 \mathrm{~mm}$ in length. The rings were mounted for isometric tension recordings and pre-tensioned to $10 \mathrm{~g}$. Tissue viability was assessed by eliciting contractions with $60 \mathrm{mM} \mathrm{KCl}$. The rings were preconstricted with U46619 to a tension of $55-85 \%$ of the 
$\mathrm{KCl}$ contraction. In experiments with PaCoA $(10 \mu \mathrm{M})$, this was added 10 min before U46619 addition. In endothelium denudation experiments, substance $\mathrm{P}(10 \mathrm{nM})$ was used to assess endothelial integrity after gentle rubbing.

\section{Measurement of changes in intracellular calcium, $\left[\mathrm{Ca}^{2+}\right]_{i}$}

HEK293 cells were grown in Eagle's minimum essential medium (EMEM) supplemented with $10 \%$ fetal calf serum (FCS) and non-essential amino acids. Cells were grown in black-walled 96-well plates (Costar, Sigma-Aldrich, Poole, Dorset, UK) at a temperature of $37^{\circ} \mathrm{C}$ in a humidified $95 \%$ air and $5 \% \mathrm{CO}_{2}$ atmosphere and cultured for $48 \mathrm{~h}$ to reach confluency. Changes in intracellular calcium, $\left[\mathrm{Ca}^{2+}\right]_{\mathrm{i}}$, were investigated using Fluo-4-AM. The culture media was aspirated and replaced with the Fluo-4-AM solution for a 45 min incubation in the presence of EMEM media, 10\% FCS and $2.5 \mathrm{mM}$ probenecid.

A loading buffer consisting of $250 \mathrm{mM}$ probenecid in HEPES-buffered saline was used to wash out the excess dye after the $45 \mathrm{~min}$ incubation period, following which antagonist was added, where appropriate, for a 30 min preincubation. Intracellular calcium responses were recorded using a FlexStation II plate reader (Molecular Devices, Winnersh, Berkshire, UK) at $37^{\circ} \mathrm{C}$ using an emission wavelength of $515 \mathrm{~nm}$.

\section{Data analysis}

For isometric tension recording and intracellular calcium measurements, results are expressed as mean \pm SEM. For analysis of $\left[\mathrm{Ca}^{2+}\right]_{\mathrm{i}}$, initial fluorescence ratios were taken as a baseline (0-16 s) and were subtracted from subsequent fluorescence ratios (16-40 s). Results are expressed as mean \pm SEM. Statistical comparisons were made using Students $t$-test or two-way ANOvA with Bonferroni post hoc test as appropriate. A $P$-value $<0.05$ was taken as statistically significant.

\section{Drugs, chemical reagents and other materials}

ADP, ATP, UTP, acetyl CoA, CoA, PaCoA, acetylcholine, methoxamine and U46619 were obtained from SigmaAldrich (Poole, Dorset, UK). 3'-Dephospho-palmitoyl-CoA was obtained from Jena Bioscience (Jena, Germany). MRS2179, MRS2500 and substance P were from Tocris Bioscience (Bristol, UK). U46619 was dissolved in ethanol as a stock solution of $10^{-2} \mathrm{M}$. All other drugs were dissolved in distilled water. EMEM, FCS, non-essential amino acids and probenecid were from Sigma-Aldrich. Fluo-4-AM was from Invitrogen (Paisley, UK). HEK293 cells were taken from the stocks of the School of Biomedical Sciences, University of Nottingham. Drug target nomenclature conforms to the British Journal of Pharmacology's Guide to Receptors and Channels (Alexander et al., 2011).

\section{Results}

\section{Effect of ADP in pre-contracted rat thoracic aorta, porcine mesenteric and porcine coronary arteries}

ADP $(0.1 \mu \mathrm{M}-1 \mathrm{mM})$ elicited concentration-dependent, complete relaxations of the rat thoracic aorta (Figure 2A). A com-
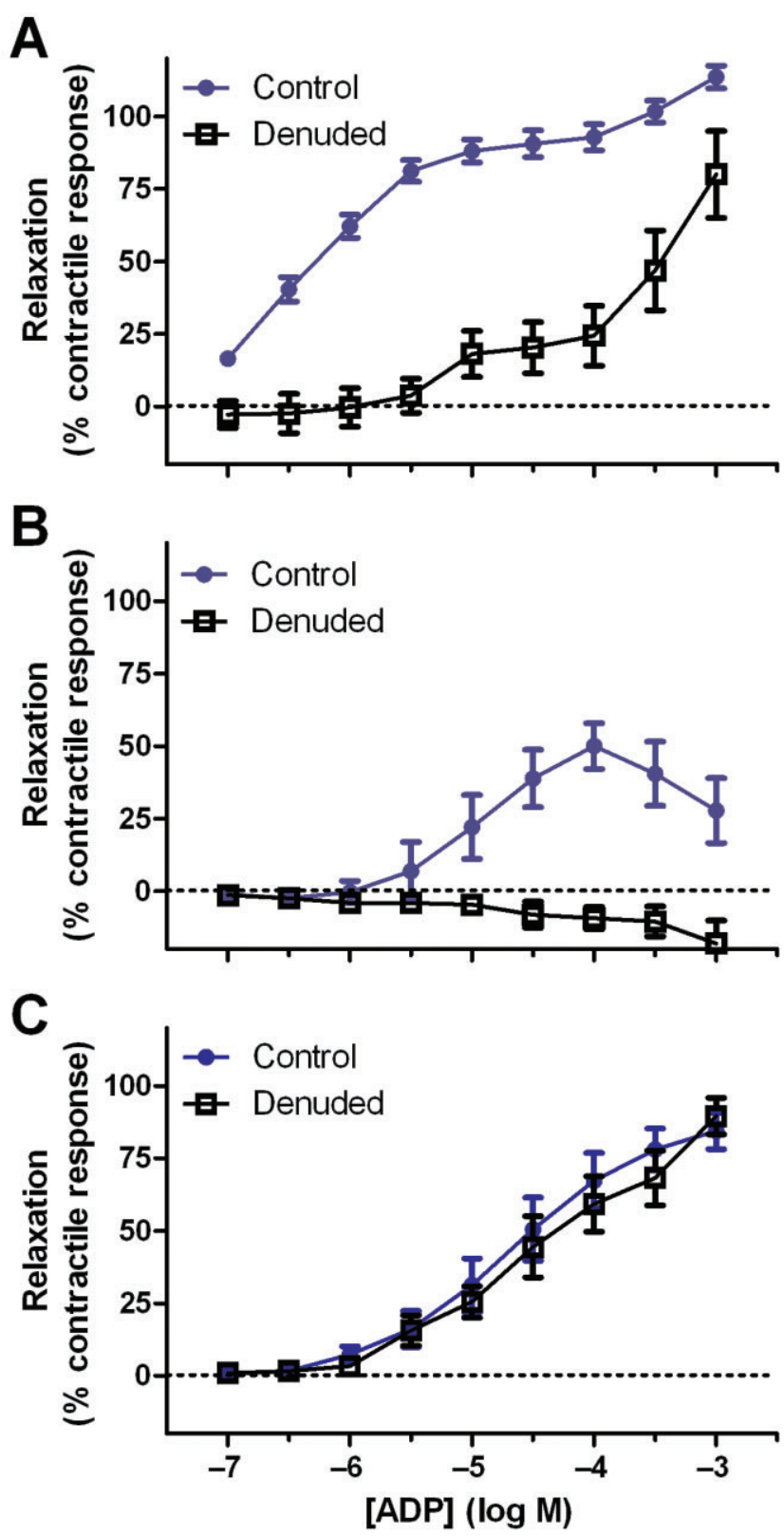

Figure 2

The effect of adenosine diphosphate (ADP) on (A) rat thoracic aorta, (B) porcine mesenteric artery, (C) porcine coronary artery. Arteries were precontracted with methoxamine for rat thoracic aorta and U46619 for porcine mesenteric artery and porcine coronary artery. Responses were evaluated in endothelium intact vessels (Control) and in those in which the endothelium had been removed (Denuded) in each of rat thoracic aorta, porcine mesenteric artery and porcine coronary artery $(n=6-19, n=8-9, n=7-10$, respectively). Results are mean \pm SEM.

parison of single-site versus two-site concentration-response curves (Prism, La Jolla, CA, USA) indicated that the two-phase option failed to fit better. Curve fitting allowed estimation of an $R_{\max }$ value $(103 \pm 4 \%), \mathrm{pEC}_{50}$ value $(6.00 \pm 0.12)$ and Hill slope $(0.81 \pm 0.07)(n=19)$. Removing the endothelium significantly attenuated the ADP-induced responses, such 
that a relaxation of $50 \%$ was achieved at approximately $300 \mu \mathrm{M}$ (Figure 2A).

In the porcine mesenteric artery, ADP $(0.1 \mu \mathrm{M}-1 \mathrm{mM})$ elicited a concentration-dependent relaxation, with a bellshaped curve, peaking at $100 \mu \mathrm{M}$ (Figure 2B). Non-linear analysis of these responses generated an estimated $R_{\max }$ value

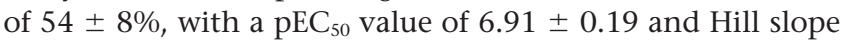
of $2.0 \pm 0.21(n=8)$. Removing the endothelium abolished the ADP-induced relaxations revealing a small contractile response (Figure 2B).

In the porcine coronary artery, ADP $(0.1 \mu \mathrm{M}-1 \mathrm{mM})$ elicited a concentration-dependent relaxation with estimates of an $R_{\max }$ value of $94 \pm 7 \%$, a pEC s0 $_{0}$ value of $4.57 \pm 0.25$ and Hill slope of $1.30 \pm 0.12(n=10)$. Removing the endothelium had no significant effect on the ADP-induced response in this vessel (Figure 2C).

\section{Effect of CoA, acetyl CoA, PaCoA,} $3^{\prime}$-dephospho-PaCoA and MRS2179 on relaxations to $A D P$ in rat thoracic aorta In the presence of CoA $(10 \mu \mathrm{M})$, acetyl CoA $(10 \mu \mathrm{M})$ and PaCoA $(10 \mu \mathrm{M})$, the mean bath concentrations of methoxamine required to elicit $50-75 \%$ of the $\mathrm{KCl}$ contraction were unchanged when compared with the control $(P>0.05$, oneway ANOVA): $1.39 \pm 0.17 \mu \mathrm{M}, n=11 ; 1.56 \pm 0.16 \mu \mathrm{M}, n=12$; $1.42 \pm 0.18 \mu \mathrm{M}, n=13$ for CoA, acetyl CoA and PaCoA, respectively compared with $1.3 \pm 0.11 \mu \mathrm{M}(n=39)$ used for the control. Similarly, there was no significant difference in methoxamine concentration and tone between control tissues and those exposed to 3'-dephospho-PaCoA.

There was a trend for $10 \mu \mathrm{M} \mathrm{CoA}$ to produce a rightward shift in the concentration-response curve to ADP, although this was not significant (Figure 3A; Table 1). Higher concentrations of CoA were not used due to cost considerations. Acetyl CoA also caused a rightward shift in the concentration-response curve to ADP (Figure 3B), with $10 \mu \mathrm{M}$ acetyl CoA causing a significant, fivefold, shift in the relaxation to ADP (Table 1). PaCoA produced a concentrationdependent rightward shift in the relaxation-response curve to ADP (Figure 3C). Schild analysis showed that concentrations of $1,3,10 \mu \mathrm{M}$ PaCoA caused shifts of 18-, 55- and 331-fold of the response to ADP, respectively $(P<0.05, P<0.01, P<0.001$, respectively; Table 1). Figure 3D shows Schild analysis for effects of PaCoA; the calculated slope was $1.73 \pm 0.4$ with an apparent $\mathrm{pA}_{2}$ value of $6.44 \pm 0.12(n=5)$.

3'-Dephospho-palmitoyl-CoA $(10 \mu \mathrm{M})$ produced a significant $(P<0.05), 20$-fold, rightward shift in the concentrationresponse curve to ADP, but had no significant effect on the maximum relaxation (Figure 4; Table 1 ). It was clearly much less potent than the same concentration of $\mathrm{PaCoA}$, which has a phosphate on the ribose at the $3^{\prime}$ position (see Figure 1). $1 \mu \mathrm{M}$ MRS2179, a selective $\mathrm{P}_{2} \mathrm{Y}_{1}$ receptor antagonist, caused a 29-fold rightward shift of the ADP response (Table 1; Supporting Information Figure S1), allowing calculation using the Gaddum transformation, of an apparent $\mathrm{pK}_{\mathrm{B}}$ value of $7.32 \pm$ $0.17(n=5)$.

The reversibility of the PaCoA antagonism was studied by evaluating consecutive ADP $(100 \mu \mathrm{M})$ responses in methoxamine-preconstricted vessels, initially in the absence of PaCoA, then in the presence of PaCoA $(10 \mu \mathrm{M})$ and then after washout of PaCoA. Control experiments were carried
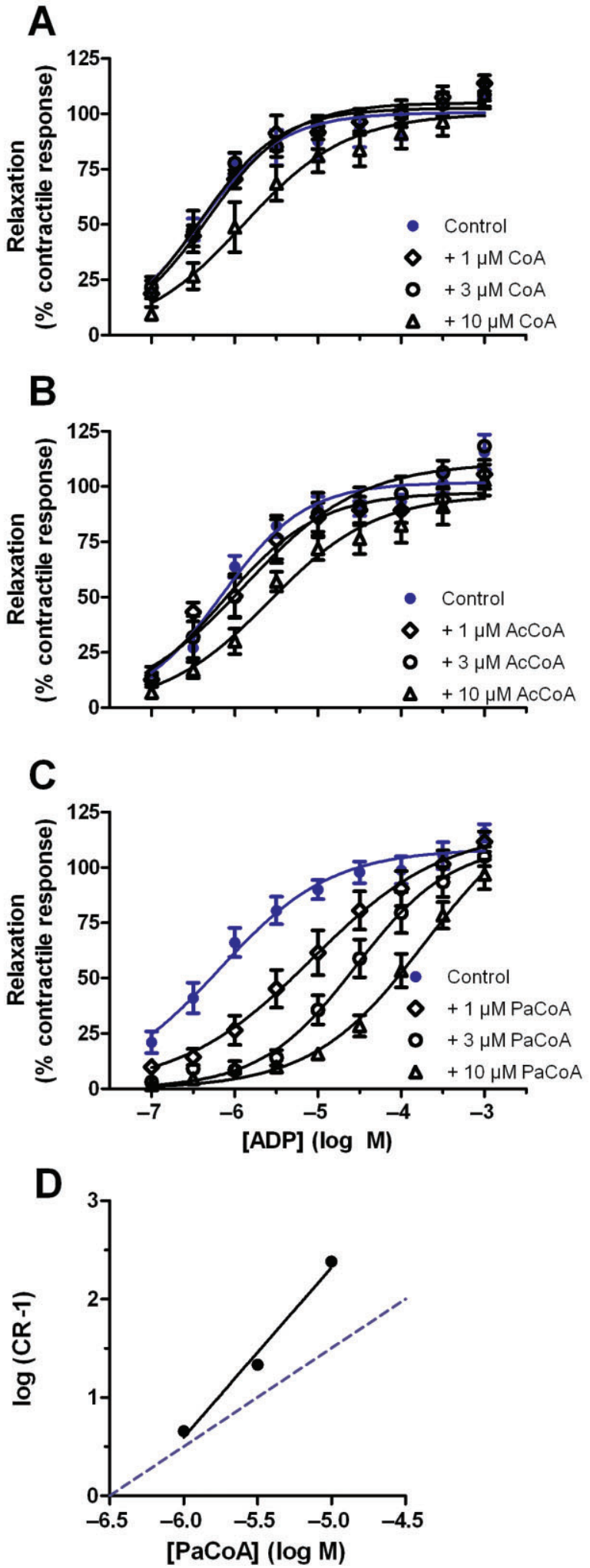

Figure 3

ADP-evoked relaxation of the rat thoracic aorta in the presence of $(A)$ CoA, (B) acetyl CoA (AcCoA) and (C) PaCoA. (D) Shows the Schild plot for the effects of PaCoA (dotted line is the line of unit slope). Vessels were precontracted with methoxamine. Data are shown as mean $\pm \operatorname{SEM}(n=5-6, n=6-7, n=7$, respectively). 


\section{Table 1}

Effect of CoA, acetyl CoA (AcCoA), PaCoA, 3'-dephospho- PaCoA and MRS2179 on ADP-evoked relaxations of the rat thoracic aorta

\begin{tabular}{|c|c|c|c|}
\hline & $\mathrm{pEC}_{50}$ & $\mathbf{R}_{\max }$ & Hill slope \\
\hline $\mathrm{ADP}+\mathrm{CoA}(1 \mu \mathrm{M})(n=6)$ & $6.19 \pm 0.10$ & $111 \pm 4$ & $0.87 \pm 0.19$ \\
\hline $\mathrm{ADP}+\mathrm{CoA}(3 \mu \mathrm{M})(n=6)$ & $6.44 \pm 0.11$ & $102 \pm 5$ & $1.21 \pm 0.20$ \\
\hline $\mathrm{ADP}+\mathrm{CoA}(10 \mu \mathrm{M})(n=6)$ & $5.74 \pm 0.29$ & $106 \pm 7$ & $0.84 \pm 0.16$ \\
\hline $\mathrm{ADP}$ (control) $(n=6)$ & $6.19 \pm 0.07$ & $101 \pm 4$ & $1.0 \pm 0.16$ \\
\hline $\mathrm{ADP}+\mathrm{AcCoA}(3 \mu \mathrm{M})(n=7)$ & $6.01 \pm 0.50$ & $112 \pm 6$ & $1.07 \pm 0.17$ \\
\hline $\mathrm{ADP}+\mathrm{AcCoA}(10 \mu \mathrm{M})(n=7)$ & $5.51 \pm 0.15^{*}$ & $102 \pm 14$ & $0.70 \pm 0.11$ \\
\hline $\operatorname{ADP}$ (control) $(n=7)$ & $6.09 \pm 0.20$ & $113 \pm 7$ & $0.97 \pm 0.30$ \\
\hline $\mathrm{ADP}+\mathrm{PaCoA}(1 \mu \mathrm{M})(n=7)$ & $4.84 \pm 0.36^{*}$ & $128 \pm 7$ & $0.64 \pm 0.08$ \\
\hline $\mathrm{ADP}+\mathrm{PaCoA}(3 \mu \mathrm{M})(n=7)$ & $4.35 \pm 0.26^{* *}$ & $122 \pm 7$ & $0.81 \pm 0.07$ \\
\hline $\operatorname{ADP}$ (control) $(n=5)$ & $6.37 \pm 0.37$ & $125.1 \pm 10$ & $0.71 \pm 0.21$ \\
\hline $\operatorname{ADP}+\operatorname{MRS} 2179(1 \mu \mathrm{M})(n=5)$ & $5.07 \pm 0.26^{*}$ & $102.3 \pm 9$ & $1.07 \pm 0.07$ \\
\hline
\end{tabular}

Results are mean \pm SEM. ${ }^{*} P<0.05$, one-way ANOVA. ${ }^{* *} P<0.01,{ }^{* *} P<0.001$, one-way ANOVA. ${ }^{\S} P<0.05$, Student's $t$-test.

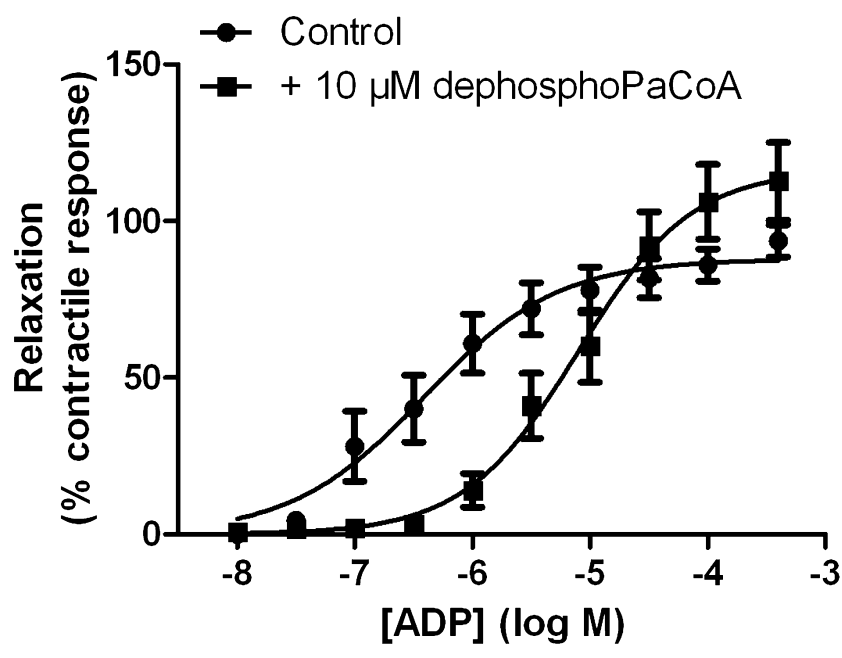

Figure 4

ADP-evoked relaxation of the rat thoracic aorta in the absence and presence of 3'-dephospho-palmitoyl-CoA. Data are shown as mean $\pm \operatorname{SEM}(n=6)$.

out with three consecutive ADP additions, at the same time intervals, in the absence of PaCoA. Repeated administration of $100 \mu \mathrm{M}$ ADP in the absence and presence of $10 \mu \mathrm{M}$ PaCoA indicated that the effect of PaCoA was reversible (data not shown). PaCoA also had no direct effect on the rat thoracic aorta when compared with time controls, in which tone was well-maintained (data not shown).
Effect of CoA, acetyl CoA, PaCoA and MRS2179 on relaxations to UTP in the rat thoracic aorta

In order to examine the selectivity of CoA analogues, UTP was employed as a vasorelaxant. Analysis of the data was carried out on responses to UTP at concentrations of up to, and including, $3 \mu \mathrm{M}$ (because at higher concentrations, UTP evoked smaller relaxations). Neither CoA $(10 \mu \mathrm{M})$ nor acetyl CoA $(10 \mu \mathrm{M})$ had a significant effect on the relaxation response to UTP (Figure 5A,B). For PaCoA, a modest, concentration-dependent rightward shift in the relaxation response curve to UTP was observed (Figure 5C). There was no significant effect of $3 \mu \mathrm{M}$ PaCoA, while $10 \mu \mathrm{M}$ PaCoA caused a threefold shift of UTP evoked relaxation. $1 \mu \mathrm{M}$ MRS2179 had no significant effect on the UTP relaxation response (Supporting Information Figure S1).

\section{Effect of PaCoA on responses to $A D P$ in porcine mesenteric arteries}

PaCoA $(10 \mu \mathrm{M})$ abolished the relaxation response to ADP in porcine mesenteric arteries (Figure 6A). MRS2500 (10 $\mu \mathrm{M})$, a selective $\mathrm{P}_{2} \mathrm{Y}_{1}$ antagonist (Kim et al., 2003), also abolished the ADP-evoked relaxation (Supporting Information Figure S2). At this same concentration, $\mathrm{PaCoA}$ was without direct effect on U46619-contracted porcine mesenteric arteries, in which tone was well-maintained (data not shown).

There were no significant differences in precontraction, or in the concentration of U46619 used to produce this, in the absence and presence of antagonists. In the absence of antagonists, U46619 caused a sustained contraction to $56 \pm$ $4 \%(n=8)$ of the $\mathrm{KCl}$ response; in the presence of PaCoA 

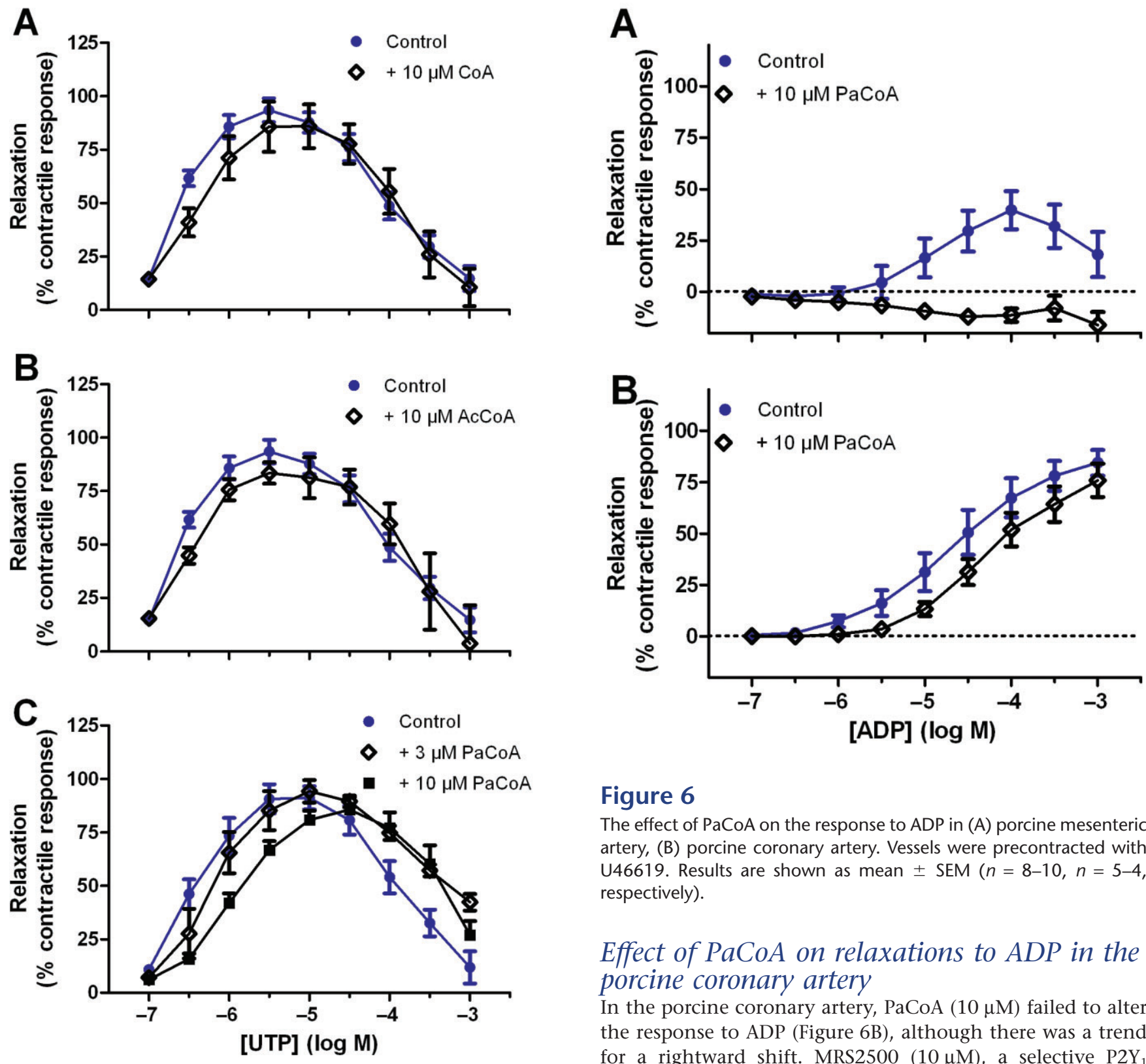

Figure 6

The effect of $\mathrm{PaCoA}$ on the response to ADP in $(A)$ porcine mesenteric artery, (B) porcine coronary artery. Vessels were precontracted with U46619. Results are shown as mean \pm SEM $(n=8-10, n=5-4$, respectively).

\section{Effect of PaCoA on relaxations to ADP in the} porcine coronary artery

In the porcine coronary artery, $\mathrm{PaCoA}(10 \mu \mathrm{M})$ failed to alter the response to ADP (Figure 6B), although there was a trend for a rightward shift. MRS2500 $(10 \mu \mathrm{M})$, a selective P2Y antagonist, also had no significant effect on the ADP-evoked responses (Supporting Information Figure S2).

A vasorelaxation of the U46619-contracted porcine coro-

Figure 5

The response of the rat thoracic aorta to UTP in the presence of $(A)$ CoA, (B) acetyl CoA (AcCoA), and (C) PaCoA $(n=6-8, n=6-8, n=$ $8-10$, respectively). Vessels were precontracted with methoxamine. Results are shown as mean \pm SEM.

$(10 \mu \mathrm{M})$ and MRS2500 $(10 \mu \mathrm{M})$ the U46619-induced contraction was $61 \% \pm 2(n=10)$ and $65 \% \pm 9(n=4)$, respectively $(P>0.05$, one-way ANOva). For the direct effect and time control experiments, the U46619-induced contraction was $51 \% \pm 9(n=4)$ and $56 \% \pm 7(n=4)$, respectively, of the $\mathrm{KCl}$-induced response. The concentration of U46619 required to induce precontraction was unchanged compared with the control in both time control and direct effect experiments $(P>0.05$, one-way ANOva). way ANOVA) was caused by $10 \mu \mathrm{M}$ PaCoA. The relaxation was slow, achieving significance after $30 \mathrm{~min}$, at which time relaxation was $30 \pm 15 \%$ with $\mathrm{PaCoA}(n=7)$, versus $1 \pm 1.5 \%$ control $(n=4)(P<0.01)$.

There were no significant differences in precontraction, or in the concentration of U46619 used to produce tone, in the absence and presence of antagonists. U46619 in the coronary artery caused a sustained contraction to $59 \pm 4 \%(n=8)$ of the $\mathrm{KCl}$ response; in the presence of $\mathrm{PaCoA}(10 \mu \mathrm{M})$ and MRS2500 $(10 \mu \mathrm{M})$, the contraction at $53 \pm 4 \%(n=10)$ and 56 $\pm 7 \%(n=4)$, respectively, was unchanged $(P>0.05$, one-way ANOVA). For the direct effect and time control experiments the U46619-induced contraction was $60 \pm 4 \%(n=8)$ and $50 \pm$ $8 \%(n=4)$, respectively, of the $\mathrm{KCl}$-induced response. The 


\section{Table 2}

The effect of PaCoA on the calcium response evoked by ADP (0.1$100 \mu \mathrm{M})$ in HEK cells

\begin{tabular}{|lll|} 
& pEC $_{\text {50 value }}$ & Hill slope \\
\hline $\mathrm{ADP}$ & $6.74 \pm 0.11$ & $1.17 \pm 0.39$ \\
$\mathrm{ADP}+0.1 \mu \mathrm{M} \mathrm{PaCoA}$ & $6.27 \pm 0.11$ & $0.60 \pm 0.15$ \\
$\mathrm{ADP}+1 \mu \mathrm{M} \mathrm{PaCoA}$ & $5.28 \pm 0.10^{\star * *}$ & $0.94 \pm 0.21$ \\
$\mathrm{ADP}+10 \mu \mathrm{M} \mathrm{PaCoA}$ & $3.65 \pm 0.22^{\star * *}$ & $0.81 \pm 0.12$ \\
\hline
\end{tabular}

The maximum response to ADP was $31062 \pm 3707 \mathrm{RFU}(n=3)$ Curves fitted for ADP in the presence of $\mathrm{PaCoA}$ were constrained to this maximum. Data are mean $\pm \mathrm{SEM}, n=3$. ${ }^{* \star *} P<0.0001$, one-way ANOVA.

\section{Table 3}

The effect of $\mathrm{PaCoA}$ on the calcium response evoked by ATP $(0.1-$ $100 \mu \mathrm{M})$ in HEK cells

\begin{tabular}{|lll|} 
& PEC 5 value & Hill slope \\
\hline ATP & $5.56 \pm 0.07$ & $1.55 \pm 0.14$ \\
ATP $+0.1 \mu \mathrm{M} \mathrm{PaCoA}$ & $5.36 \pm 0.02$ & $1.45 \pm 0.25$ \\
ATP $+1 \mu \mathrm{M} \mathrm{PaCoA}$ & $4.40 \pm 0.11$ & $0.82 \pm 0.12$ \\
ATP $+10 \mu \mathrm{M} \mathrm{PaCoA}$ & $2.58 \pm 0.55^{\star * *}$ & $0.40 \pm 0.13^{*}$ \\
\hline
\end{tabular}

The maximum response to ATP was $26520 \pm 1999 \mathrm{RFU}(n=3)$. Curves fitted for ATP in the presence of $\mathrm{PaCoA}$ were constrained to this maximum. Data are mean $\pm \mathrm{SEM}, n=3$. ${ }^{*} P<0.05,{ }^{* * *} P$ $<0.0001$, one-way ANOVA.

concentration of U46619 required to induce precontraction was unchanged compared with the control in both time control and direct effect experiments $(P>0.05$, one-way ANOVA).

\section{Effect of CoA analogues on adenine} nucleotide-evoked $\left[\mathrm{Ca}^{2+}\right]_{i}$ elevation in HEK293 cells

ADP and ATP (0.1-100 $\mu \mathrm{M})$ evoked concentration-dependent calcium responses in HEK293 cells with pEC $_{50}$ values of $6.7 \pm$ $0.1(n=3)$ and $5.6 \pm 0.1(n=3)$, respectively (Tables 2 and 3).

PaCoA $(0.1-10 \mu \mathrm{M})$ caused a concentration-dependent rightward shift in the calcium release evoked by ADP (Figure 7A). $\mathrm{pEC}_{50}, R_{\max }$ and Hill slope values for PaCoA are shown in Table 2. Schild analysis of the effects of PaCoA against ADP allowed calculation of an apparent $\mathrm{pA}_{2}$ value of $7.2 \pm 0.2$, with a slope of $1.4 \pm 0.2(n=3$, Figure 7C).

PaCoA $(0.1-10 \mu \mathrm{M})$ also produced a concentrationdependent rightward shift in the response curve to ATP (Figure $7 \mathrm{~B}$ ). $\mathrm{pEC}_{50}, R_{\max }$ and Hill slope values are reported in Table 3. In order to calculate $\mathrm{pA}_{2}$ values, data were constrained, such that the top was fixed to the maximum response evoked in the absence of antagonist for each individual experiment. Schild analysis gave an apparent $\mathrm{pA}_{2}$ value of $7.0 \pm 0.3$ and a slope of $1.6 \pm 0.2(n=3$, Figure 7C).

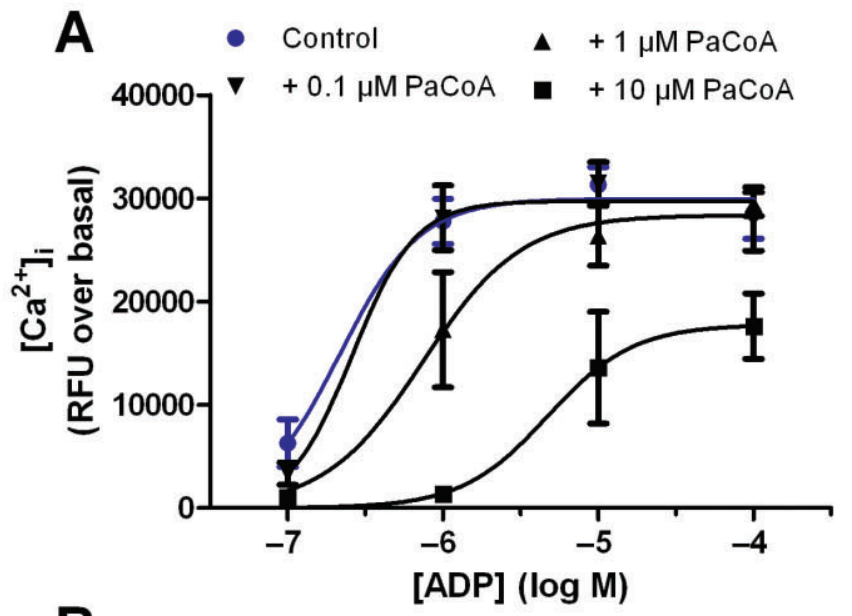

B
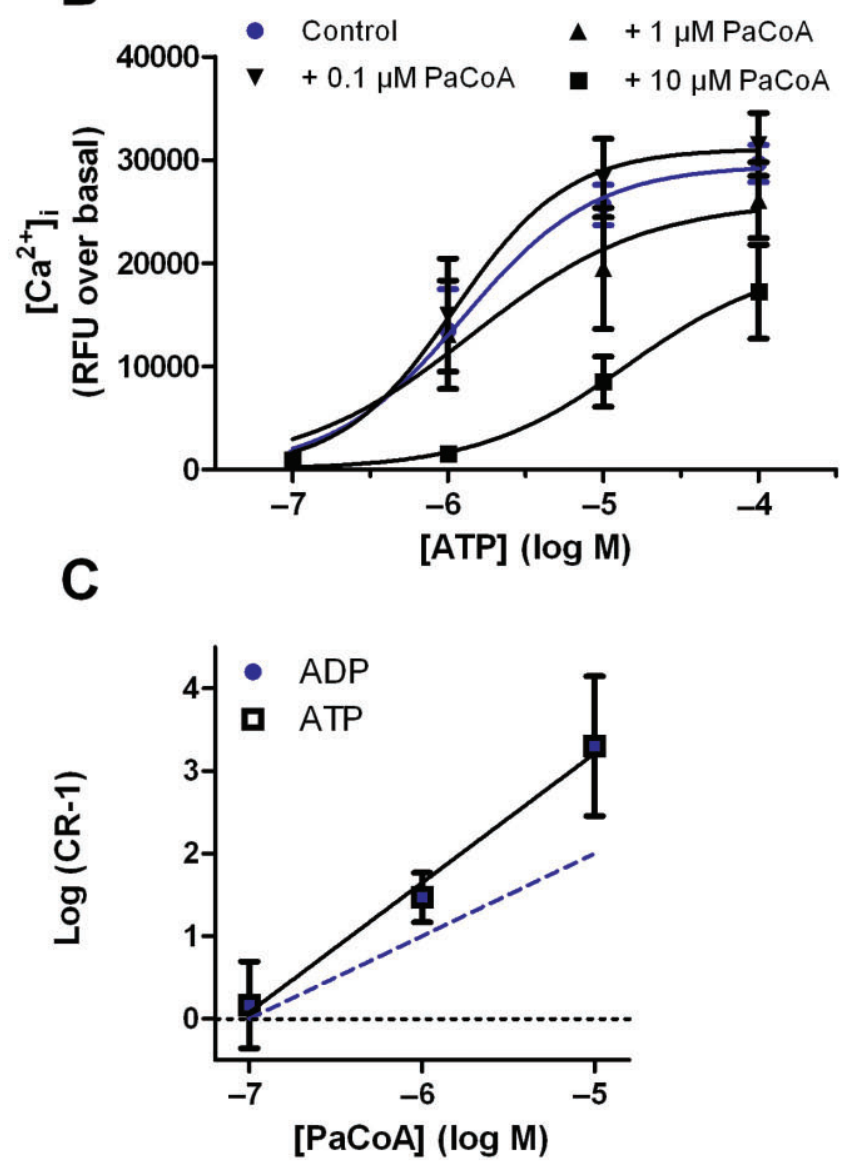

Figure 7

Effect of different concentrations of $\mathrm{PaCoA}$ on the calcium response of HEK293 cells to (A) ADP $(n=6)$, (B) ATP $(n=6)$, (C) Schild plots for ADP and ATP in the presence of $\mathrm{PaCoA}(n=3)$ (dotted line is the line of unit slope). Note that the plots for ADP and ATP are superimposed and appear as a single line. Results are mean \pm SEM.

ADP- and UTP-mediated elevations of $\left[\mathrm{Ca}^{2+}\right]_{\mathrm{i}}$ were compared in HEK293 cells. ADP, at $10 \mu \mathrm{M}$, caused a transient response with a peak of $32585 \pm 2364 \mathrm{RFU}$ (relative fluorescence units) over basal ( $n=11$ ), which occurred within $25-30$ 
seconds of drug administration. UTP, at $300 \mu \mathrm{M}$, evoked a smaller elevation of $\left[\mathrm{Ca}^{2+}\right]_{i}$ with a mean of $16228 \pm 2324 \mathrm{RFU}$ $(n=10,49 \pm 4 \%$ of the response to ADP), with a latency of 23-30 s.

ADP-evoked responses were significantly inhibited in the presence of either $10 \mu \mathrm{M}$ PaCoA (residual response $45 \pm 9 \%$ of control, $n=11$ ) or $10 \mu \mathrm{M}$ MRS2500 (residual response $5 \pm$ $1 \%$ of control, $n=7$ ), but not in the presence of $1 \mu \mathrm{M} \mathrm{PaCoA}$ (Supporting Information Figure S3). Responses to ADP were not significantly altered in the presence of neither 1 nor $10 \mu \mathrm{M}$ CoA, acetyl CoA or oleoyl CoA.

Responses to UTP were not significantly altered in the presence of neither 1 nor $10 \mu \mathrm{M}$ PaCoA, CoA, acetyl CoA, oleoyl CoA or MRS2500 (Supporting Information Figure S3).

\section{Discussion}

In the present study, the effects of acyl-CoA derivatives on relaxation of rat preconstricted thoracic aorta by ADP and UTP, agonists for $\mathrm{P}_{2} \mathrm{Y}_{1}$ and $\mathrm{P}_{2} \mathrm{Y}_{2 / 4}$ receptors, respectively, were examined. The results indicate that, of the derivatives used, PaCoA was the most potent, acting as an antagonist with apparent selectivity for the endothelial $\mathrm{P}_{2} \mathrm{Y}_{1}$ receptor. A crucial role of the 3 -ribose phosphate in mediating the inhibitory effects of PaCoA was demonstrated. In HEK293 cells, PaCoA selectively inhibited $\mathrm{P}_{2} \mathrm{Y}_{1}$ receptor-mediated ADP- and ATP-induced increases in $\left[\mathrm{Ca}^{2+}\right] \mathrm{i}$ with no effect at $\mathrm{P}_{2 / 4}$ receptors stimulated by UTP. In porcine mesenteric artery, both $\mathrm{PaCoA}$, and the selective $\mathrm{P}_{2} \mathrm{Y}_{1}$ receptor antagonist MRS2500, abolished ADP-evoked endotheliumdependent relaxations. In contrast, in porcine coronary artery, PaCoA and MRS2500 had no significant effect on ADP-evoked endothelium-independent relaxations, suggesting involvement of a receptor other than $\mathrm{P}_{2} \mathrm{Y}_{1}$ in this blood vessel.

\section{Effects of ADP and UTP in rat thoracic aorta}

ADP has previously been shown to induce endotheliumdependent relaxations mediated by $\mathrm{P}_{2} \mathrm{Y}_{1}$ receptors in the rat thoracic aorta (Dol-Gleizes et al., 1999). In the present study, we confirmed that the response to ADP was endotheliumdependent. The responses clearly involved $\mathrm{P}_{2} \mathrm{Y}_{1}$ receptors because they were blocked by a selective $\mathrm{P}_{2} \mathrm{Y}_{1}$ antagonist, MRS2179 (Boyer et al., 1996b), and the pEC $_{50}$ value for ADP of 6.00 was similar to $\mathrm{pEC}_{50}$ values reported previously in rat (6.2) (Dol-Gleizes et al., 1999) and mouse (6.22) thoracic aorta (Guns et al., 2005).

Concentration-response curves to UTP were insensitive to MRS2179, consistent with an action of UTP at a target other than the $\mathrm{P}_{2} \mathrm{Y}_{1}$ receptor; the $\mathrm{P}_{2} \mathrm{Y}_{2}$ receptor is a likely target, but $\mathrm{P}_{2} \mathrm{Y}_{6}$ receptors have been shown to mediate endotheliumdependent relaxation to UTP in mouse aorta (Buvinic et al., 2002; Guns et al., 2006; Bar et al., 2008). At concentrations higher than $3 \mu \mathrm{M}$, UTP-evoked relaxations were reversed, possibly involving actions at contractile $\mathrm{P}_{2} \mathrm{Y}_{2 / 4}$ receptors on the smooth muscle (Eltze and Ullrich, 1996). The agonist potency $\left(\mathrm{pEC}_{50}\right)$ of UTP-evoked relaxations in the current study was 6.64 , similar to that previously reported (5.83)
(Dol-Gleizes et al., 1999) and suggested to be mediated through $\mathrm{P}_{2} \mathrm{Y}_{2}$ receptors.

\section{Effect of CoA, acetyl CoA, PaCoA and $3^{\prime}$-dephospho-PaCoA on responses to ADP and UTP in the rat thoracic aorta}

PaCoA produced concentration-dependent inhibition of ADP-evoked relaxation of the rat thoracic aorta, and its effects were reversible, as described at recombinant $\mathrm{P}_{2} \mathrm{Y}_{1}$ receptors in Xenopus oocytes (Coddou et al., 2003). PaCoA had no direct effect on the rat thoracic aorta, and was more potent than CoA and acetyl CoA as an antagonist at $\mathrm{P}_{2} \mathrm{Y}_{1}$ receptors; indeed, $10 \mu \mathrm{M}$ PaCoA caused an approximately 330-shift of ADP-evoked relaxations, while acetyl CoA at the same concentration produced a fivefold shift and CoA was ineffective. This is in agreement with findings in Xenopus oocytes and human platelets (Coddou et al., 2003; Manolopoulos et al., 2008). This increase in potency appears to be due to the increase in hydrophobicity from CoA, acetyl CoA to PaCoA (Coddou et al., 2003). The nucleotide moiety of the CoA compounds exhibits structural similarities with ADP, which suggests a ligand-binding domain focussed on the purine binding site. In addition, it is possible that a hydrophobic pocket adjacent to the purine binding site accommodates the lipophilic acyl-substituent and helps to stabilize the interaction of the antagonist with the receptor (Coddou et al., 2003). Thus, the increase in potency of these compounds with increase in chain length may involve the side chain adding to the stability of the CoA moiety.

Structurally, the CoA headgroup resembles ADP in that both have adenine and ribose moieties, and a pyrophosphate group linked to the $5^{\prime}$-position of the ribose (Figure 1 ). However, an important structural difference is that the CoA headgroup has an additional phosphate linked to the ribose at the 3 -position. In the present study, we have shown that 3'-dephospho-PaCoA is a significantly weaker antagonist than PaCoA at $\mathrm{P}_{2} \mathrm{Y}_{1}$ receptors in rat aorta (20-fold vs. 331fold shift in the ADP-response curve at $10 \mu \mathrm{M}$ of the CoA compounds). Thus, the 3 -phosphate appears to be critical for mediating the inhibitory effects of $\mathrm{PaCoA}$ at $\mathrm{P}_{2} \mathrm{Y}_{1}$ receptors. Consistent with the importance of the $3^{\prime}$-phosphate are studies showing that adenosine $2^{\prime}, 5^{\prime}$-diphosphate and adenosine $3^{\prime}, 5^{\prime}$-diphosphate are competitive antagonists at the $\mathrm{P}_{2} \mathrm{Y}_{1}$ receptor although these compounds do not have a pyrophosphate group, just a single phosphate attached to the ribose (Boyer et al., 1996a). The 3'-phosphate was also shown to be significant in the intracellular actions of CoA compounds at potassium channels (Rapedius et al., 2005). The crucial role of the 3'-phosphate in the antagonist activity of CoA compounds at $\mathrm{P}_{2} \mathrm{Y}_{1}$ receptors has not previously been reported.

CoA and acetyl CoA had no significant effect on UTPevoked relaxations in the rat thoracic aorta, while PaCoA caused a significant rightward shift. This shift was small (threefold) when compared with the 331-fold shift caused by PaCoA to the ADP-evoked $\mathrm{P}_{2} \mathrm{Y}_{1}$ receptor-mediated relaxations. This indicates that $\mathrm{PaCoA}$ and acetyl CoA are reasonably selective for $\mathrm{P}_{2} \mathrm{Y}_{1}$ versus $\mathrm{P}_{2} \mathrm{Y}_{2 / 4}$ receptors, consistent with their effects at recombinant $\mathrm{P}_{2} \mathrm{Y}_{1}$ and $\mathrm{P}_{2} \mathrm{Y}_{2}$ receptors (Coddou et al., 2003). 
Effect of PaCoA and MRS2500 on

ADP-evoked responses in porcine

mesenteric arteries

ADP caused a concentration-dependent, endotheliumdependent, vasorelaxation of the porcine mesenteric artery with a $\mathrm{pEC}_{50}$ value of 6.9 , similar to that calculated for ADP activation of $\mathrm{P}_{2} \mathrm{Y}_{1}$ receptors (6.8) in the rat mesenteric arterial bed (Buvinic et al., 2002). The involvement of $\mathrm{P} 2 \mathrm{Y}_{1}$ receptors was confirmed because MRS2500 abolished the ADP-evoked relaxations. PaCoA $(10 \mu \mathrm{M})$ also eliminated ADP-evoked relaxations in the porcine mesenteric artery, without eliciting a direct effect, consistent with our findings in rat thoracic aorta.

Effect of PaCoA and MRS2500 on ADP-evoked responses in porcine coronary arteries

ADP elicited a concentration-dependent, endotheliumindependent, relaxation of the porcine coronary artery. PaCoA failed to affect these responses, indicating that they are not mediated through $\mathrm{P}_{2} \mathrm{Y}_{1}$ receptors. Moreover, MRS2500 also had no significant effect on these relaxations. These findings indicate that these receptors mediating direct smooth muscle vasorelaxation in the porcine coronary artery are not $\mathrm{P}_{2} \mathrm{Y}_{1}$ receptors. We have reported previously that ADP mediates endothelium-independent relaxation of porcine coronary artery via a novel mechanism involving release of adenosine and activation of $\mathrm{A}_{2 \mathrm{~A}}$ receptors independently of $\mathrm{P}_{2} \mathrm{Y}_{1}$ receptors (Rayment et al., 2007). The potency of ADP $\left(\mathrm{pEC}_{50} 4.6\right)$ at eliciting vasorelaxation in the porcine coronary artery observed here is similar to that reported by us previously ( $\mathrm{pEC}_{50}$ 5.3) (Rayment et al., 2007), and much lower than that observed in both porcine mesenteric artery ( $\mathrm{pEC}_{50}$ 6.9) and rat thoracic aorta $\left(\mathrm{pEC}_{50} 6.0\right)$, further indicating a lack of involvement of $\mathrm{P}_{2} \mathrm{Y}_{1}$ receptors.

Interestingly, in the porcine coronary artery, $\mathrm{PaCoA}$ alone caused a significant relaxation of the U46619 pre-contracted tone. The response was slow, suggesting a direct action on the smooth muscle. This direct relaxant effect of PaCoA in the porcine coronary artery is in contrast with its lack of action in the porcine mesenteric artery and rat thoracic aorta. The mechanism of this direct, tissue-dependent, relaxant effect of PaCoA awaits further characterization.

\section{Effect of CoA derivatives at $A D P$ responses in HEK293 cells}

Concentration-dependent elevation of $\left[\mathrm{Ca}^{2+}\right]_{i}$ was produced in the presence of ADP, ATP or UTP. The potency of ADP was $>10$-fold more than that of ATP ( $\mathrm{pEC}_{50} 6.7,5.6$, respectively). MRS2500 effectively blocked ADP responses in HEK293 cells, while leaving responses to UTP unaltered. These data are consistent with the fact that uridine nucleotides are mostly inactive at $\mathrm{P}_{2} \mathrm{Y}_{1}$ receptors and that $\mathrm{P} 2 \mathrm{Y}_{1}$ receptors are more sensitive to adenine nucleotide diphosphates than triphosphates (von Kugelgen, 2006).

PaCoA was a potent and selective (vs. UTP at $\mathrm{P}_{2} \mathrm{Y}_{2 / 4}$ receptors) antagonist of the native human $\mathrm{P}_{2} \mathrm{Y}_{1}$ receptor in HEK293 cells, while CoA, acetyl CoA and oleoyl CoA had no significant effect. In rat thoracic aorta, acetyl CoA caused a small but significant shift in ADP-evoked relaxations through the $\mathrm{P}_{2} \mathrm{Y}_{1}$ receptor. Coddou et al. (2003) suggested that the increase in potency of $\mathrm{PaCoA}$, compared with CoA and acetyl CoA, may be due to interaction of the lipophilic acyl-substituent with a hydrophobic pocket close to the binding site. In addition, they suggested that bulkiness may also play a critical role. Despite having a double bond, which reduces flexibility and might be expected to increase potency (Coddou et al., 2003), oleoyl CoA had no significant effect on the ADP responses, although it has higher lipophilicity and bulkiness. Our findings agree with those of Manolopoulos et al. in platelets where CoA analogues containing saturated fatty acids provided greater inhibition than unsaturated fatty acids (Manolopoulos et al., 2008).

\section{Acyl derivatives of $\mathrm{CoA}$ as endogenous modulators of $\mathrm{P} \mathrm{Y}_{1}$ receptors}

In this investigation, $\mathrm{PaCoA}$ was shown to act as a potent antagonist with apparent selectivity for $\mathrm{P}_{2} \mathrm{Y}_{1}$ receptors. However, the mechanism by which PaCoA acts remains to be clarified. The simplest interpretation is that CoA compounds, because of their structural similarity with ADP, compete for the same binding site as the $\mathrm{P}_{2} \mathrm{Y}_{1}$ receptor at the extracellular surface, although the Schild analyses suggest a more complicated locus of action. One intriguing possibility is that acylCoA derivatives may act on the intracellular face of the plasma membrane to regulate $\mathrm{P}_{2} \mathrm{Y}_{1}$ receptor function. Longchain acyl-CoAs have a high affinity for phospholipid bilayers and have been shown to associate with cell membranes by insertion of the fatty acyl chain into the bilayer (Powell et al., 1985). Thus, the action of these compounds may be facilitated by the fact that they integrate into the right place, in membranes, that makes them available to interact with $\mathrm{P}_{2} \mathrm{Y}_{1}$ receptors.

In vivo administration of $\mathrm{P}_{2} \mathrm{Y}_{1}$ antagonists, MRS2179 and MRS2500, in pigs and mice, respectively, has provided evidence for a role of the $\mathrm{P}_{2} \mathrm{Y}_{1}$ receptor in post ischemic coronary hypaeremia and thrombosis (Olivecrona et al., 2004; Hechler et al., 2006), although $\mathrm{P}_{2} \mathrm{Y}_{1}$ receptors were not involved in reactive hyperaemia to a brief episode of cardiac ischaemia in dogs (Bender et al., 2011). MRS2179 and MRS2500 significantly reduced post-ischemic hyperaemia and inhibited both systemic and localized arterial thrombosis, respectively; this supports the concept that targeting the $\mathrm{P}_{2} \mathrm{Y}_{1}$ receptor can be a complement, or alternative, to current clinical management of reperfusion injury and in antithrombotic therapy. $\mathrm{PaCoA}$ is an attractive lead for assessing these in vivo effects, because it was reported to have antiplatelet activity acting mainly at $\mathrm{P} 2 \mathrm{Y}_{1}$ receptors ex vivo, to be an antagonist at recombinant $\mathrm{P}_{1} \mathrm{Y}_{1}$ receptors (Coddou et al., 2003; Manolopoulos et al., 2008) and, in this study, to be an antagonist at endogenous vascular $\mathrm{P}_{2} \mathrm{Y}_{1}$ receptors in rat thoracic aorta and porcine mesenteric artery, as well as at native $\mathrm{P}_{2} \mathrm{Y}_{1}$ receptors in HEK293 cells. Future studies directed at measuring plasma levels of acyl CoA derivatives and their release from cells (e.g. endothelial cells) are warranted to give insight into the patho/ physiological roles of these endogenous compounds at vascular $\mathrm{P}_{2} \mathrm{Y}_{1}$ receptors. 
In conclusion, these results raise the possibility of an endogenous selective regulation of P2 receptor signalling involving inhibition of $\mathrm{P}_{2} \mathrm{Y}_{1}$ receptors via CoA compounds. The present results indicate that, of the acyl CoA derivatives used in this study (CoA, acetyl CoA, PaCoA and oleoyl CoA), the most potent was $\mathrm{PaCoA}$ acting as an antagonist with apparent selectivity for the $\mathrm{P}_{2} \mathrm{Y}_{1}$ receptor across three species and tissues, rat thoracic aorta, porcine mesenteric artery and HEK293 cells. A crucial role of the 3 '-ribose phosphate in mediating the inhibitory effects of $\mathrm{PaCoA}$ at $\mathrm{P}_{2} \mathrm{Y}_{1}$ receptors was demonstrated.

\section{Acknowledgements}

This research was funded by the Jordanian Government.

\section{Conflicts of interest}

None.

\section{References}

Agius L, Wright PD, Alberti KG (1987). Carnitine acyltransferases and acyl-CoA hydrolases in human and rat liver. Clin Sci (Lond) 73: $3-10$.

Alefishat E, Alexander SPH, Ralevic V (2010). Effect of palmitoyl CoA on ADP-evoked vasorelaxations in porcine isolated coronary and mesenteric arteries. Available at: http://www.fasebj.org/cgi/ content/meeting abstract/24/1_MeetingAbstracts/1b426.

Alexander SPH, Mathie A, Peters JA (2011). Guide to Receptors and Channels (GRAC), 5th edition (2011). Br J Pharmacol 164 (Suppl. 1): S1-S324.

Bar I, Guns P-J, Metallo J, Cammarata D, Wilkin F, Boeynaems J-M et al. (2008). Knockout mice reveal a role for $\mathrm{P}_{2} \mathrm{Y}_{6}$ receptor in macrophages, endothelial cells, and vascular smooth muscle cells. Mol Pharmacol 74: 777-784

Bender SB, Berwick ZC, Laughlin MH, Tune JD (2011). Functional contribution of $\mathrm{P}_{2} \mathrm{Y}_{1}$ receptors to the control of coronary blood flow. J Appl Physiol 111: 1744-1750.

Boyer JL, Romero-Avila T, Schachter JB, Harden TK (1996a). Identification of competitive antagonists of the $\mathrm{P}_{2} \mathrm{Y}_{1}$ receptor. Mol Pharmacol 50: 1323-1329.

Boyer JL, Siddiqi S, Fischer B, Romero-Avila T, Jacobson KA Harden TK (1996b). Identification of potent P2Y-purinoceptor agonists that are derivatives of adenosine $5^{\prime}$-monophosphate. $\mathrm{Br} \mathrm{J}$ Pharmacol 118: 1959-1964.

Boylan JG, Hamilton JA (1992). Interactions of acyl-coenzyme A with phosphatidylcholine bilayers and serum albumin.

Biochemistry 31: 557-567.

Bultmann R, Tuluc F, Starke K (1998). On the suitability of adenosine 3 '-phosphate 5 '-phosphosulphate as a selective P2Y receptor antagonist in intact tissues. Eur J Pharmacol 359: 95-101.

Buvinic S, Briones R, Huidobro-Toro JP (2002). P2Y(1) and P2Y(2) receptors are coupled to the NO/cGMP pathway to vasodilate the rat arterial mesenteric bed. Br J Pharmacol 136: 847-856.
Coddou C, Loyola G, Boyer JL, Bronfman M, Huidobro-Toro JP (2003). The hypolipidemic drug metabolites nafenopin-CoA and ciprofibroyl-CoA are competitive $\mathrm{P}_{2} \mathrm{Y}_{1}$ receptor antagonists. FEBS Lett 536: 145-150.

Corr L, Burnstock G (1994). Analysis of P2-purinoceptor subtypes on the smooth muscle and endothelium of rabbit coronary artery. J Cardiovasc Pharmacol 23: 709-715.

Dol-Gleizes F, Mares AM, Savi P, Herbert JM (1999). Relaxant effect of 2-methyl-thio-adenosine diphosphate on rat thoracic aorta: effect of clopidogrel. Eur J Pharmacol 367: 247-253.

Eltze M, Ullrich B (1996). Characterization of vascular P2 purinoceptors in the rat isolated perfused kidney. Eur J Pharmacol 306: $139-152$

Fischer W, Franke H, Groger-Arndt H, Illes P (2005). Evidence for the existence of $\mathrm{P}_{2} \mathrm{Y}_{1,2,4}$ receptor subtypes in HEK-293 cells: reactivation of $\mathrm{P}_{2} \mathrm{Y}_{1}$ receptors after repetitive agonist application. Naunyn Schmiedebergs Arch Pharmacol 371: 466-472.

Guns PJ, Korda A, Crauwels HM, Van Assche T, Robaye B, Boeynaems JM et al. (2005). Pharmacological characterization of nucleotide P2Y receptors on endothelial cells of the mouse aorta. Br J Pharmacol 146: 288-295.

Guns PJ, Van Assche T, Fransen P, Robaye B, Boeynaems JM, Bult H (2006). Endothelium-dependent relaxation evoked by ATP and UTP in the aorta of $\mathrm{P}_{2} \mathrm{Y}_{2}$-deficient mice. Br J Pharmacol 147: 569-574.

Hansmann G, Bultmann R, Tuluc F, Starke K (1997). Characterization by antagonists of P2-receptors mediating endothelium-dependent relaxation in the rat aorta. Naunyn Schmiedebergs Arch Pharmacol 356: 641-652.

Harrington LS, Evans RJ, Wray J, Norling L, Swales KE, Vial C et al. (2007). Purinergic $2 \mathrm{X}_{1}$ receptors mediate endothelial dependent vasodilation to ATP. Mol Pharmacol 72: 1132-1136.

Harris RA, Farmer B, Ozawa T (1972). Inhibition of the mitochondrial adenine nucleotide transport system by oleyl CoA. Arch Biochem Biophys 150: 199-209.

Hechler B, Nonne C, Roh EJ, Cattaneo M, Cazenave JP, Lanza F et al. (2006). MRS2500 [2-iodo-N6-methyl-(N)-methanocarba-2'deoxyadenosine-3', 5'-bisphosphate], a potent, selective, and stable antagonist of the platelet $\mathrm{P}_{2} \mathrm{Y}_{1}$ receptor with strong antithrombotic activity in mice. J Pharmacol Exp Ther 316: 556-563.

Hertz R, Magenheim J, Berman I, Bar-Tana J (1998). Fatty acyl-CoA thioesters are ligands of hepatic nuclear factor-4alpha. Nature 392: 512-516.

Keef KD, Pasco JS, Eckman DM (1992). Purinergic relaxation and hyperpolarization in guinea pig and rabbit coronary artery: role of the endothelium. J Pharmacol Exp Ther 260: 592-600.

Kim HS, Ohno M, Xu B, Kim HO, Choi Y, Ji XD et al. (2003). 2-Substitution of adenine nucleotide analogues containing a bicyclo[3.1.0] hexane ring system locked in a northern conformation: enhanced potency as $\mathrm{P}_{2} \mathrm{Y}_{1}$ receptor antagonists. J Med Chem 46: 4974-4987.

Knudsen J, Neergaard TB, Gaigg B, Jensen MV, Hansen JK (2000). Role of acyl-CoA binding protein in acyl-CoA metabolism and acyl-CoA-mediated cell signaling. J Nutr 130: 294S-298S.

Lerner E, Shug AL, Elson C, Shrago E (1972). Reversible inhibition of adenine nucleotide translocation by long chain fatty acyl coenzyme A esters in liver mitochondria of diabetic and hibernating animals. J Biol Chem 247: 1513-1519.

Li QL, Yamamoto N, Inoue A, Morisawa S (1990). Fatty acyl-CoAs are potent inhibitors of the nuclear thyroid hormone receptor in vitro. J Biochem 107: 699-702. 
Manolopoulos P, Glenn JR, Fox SC, May JA, Dovlatova NL, Tang SW et al. (2008). Acyl derivatives of coenzyme A inhibit platelet function via antagonism at $\mathrm{P}_{2} \mathrm{Y}_{1}$ and $\mathrm{P}_{2} \mathrm{Y}_{12}$ receptors: a new finding that may influence the design of anti-thrombotic agents. Platelets 19: 134-145.

Olivecrona GK, Goteberg M, Harnek J, Wang L, Jacobson KA, Erlinge D (2004). Coronary artery reperfusion: the ADP receptor P2Y(1) mediates early reactive hyperemia in vivo in pigs. Purinergic Signal 1: 59-65.

Pelsers MM, Chapelle JP, Knapen M, Vermeer C, Muijtjens AM, Hermens WT et al. (1999). Influence of age and sex and day-to-day and within-day biological variation on plasma concentrations of fatty acid-binding protein and myoglobin in healthy subjects. Clin Chem 45: 441-443.

Powell GL, Tippett PS, Kiorpes TC, McMillinwood J, Coll KE, Schulz H et al. (1985). Fatty acyl-CoA as an effector molecule in metabolism. Fed Proc 44: 81-84.

Ralevic V, Burnstock G (1998). Receptors for purines and pyrimidines. Pharmacol Rev 50: 413-492.

Rapedius M, Soom M, Shumilina E, Schulze D, Schönherr R, Kirsch C et al. (2005). Long chain CoA esters as competitive antagonists of phosphatidylinositol 4,5-bisphosphate activation in Kir channels. J Biol Chem 280: 30760-30767.

Rayment SJ, Ralevic V, Barrett DA, Cordell R, Alexander SP (2007). A novel mechanism of vasoregulation: ADP-induced relaxation of the porcine isolated coronary artery is mediated via adenosine release. FASEB J 21: 577-585.

Riedel MJ, Light PE (2005). Saturated and cis/trans unsaturated acyl CoA esters differentially regulate wild-type and polymorphic beta-cell ATP-sensitive K+ channels. Diabetes 54: 2070-2079.

Rose'Meyer RB, Hope W (1990). Evidence that A2 purinoceptors are involved in endothelium-dependent relaxation of the rat thoracic aorta. Br J Pharmacol 100: 576-580.

Saetrum Opgaard O, Edvinsson L (1997). Mechanical properties and effects of sympathetic co-transmitters on human coronary arteries and veins. Basic Res Cardiol 92: 168-180.

Sambandam N, Lopaschuk GD (2003). AMP-activated protein kinase (AMPK) control of fatty acid and glucose metabolism in the ischemic heart. Prog Lipid Res 42: 238-256.

Schachter JB, Boyer JL, Li Q, Nicholas RA, Harden TK (1997). Fidelity in functional coupling of the rat $\mathrm{P}_{2} \mathrm{Y}_{1}$ receptor to phospholipase C. Br J Pharmacol 122: 1021-1024.
Schroeder F, Petrescu AD, Huang H, Atshaves BP, McIntosh AL, Martin GG et al. (2008). Role of fatty acid binding proteins and long chain fatty acids in modulating nuclear receptors and gene transcription. Lipids 43: 1-17.

Simonsen U, Garcia-Sacristan A, Prieto D (1997). Involvement of ATP in the non-adrenergic non-cholinergic inhibitory neurotransmission of lamb isolated coronary small arteries. Br J Pharmacol 120: 411-420.

Tippett PS, Neet KE (1982). Specific inhibition of glucokinase by long chain acyl coenzymes A below the critical micelle concentration. J Biol Chem 257: 12839-12845.

Van Breda E, Keizer HA, Vork MM, Surtel DA, De Jong YF, Van Der Vusse GJ et al. (1992). Modulation of fatty-acid-binding protein content of rat heart and skeletal muscle by endurance training and testosterone treatment. Pflugers Arch 421: 274-279.

Von Kugelgen I (2006). Pharmacological profiles of cloned mammalian P2Y-receptor subtypes. Pharmacol Ther 110: 415-432.

Wunderlich MT, Hanhoff T, Goertler M, Spener F, Glatz JF, Wallesch CW et al. (2005). Release of brain-type and heart-type fatty acid-binding proteins in serum after acute ischaemic stroke. J Neurol 252: 718-724.

\section{Supporting information}

Additional Supporting Information may be found in the online version of this article at the publisher's web-site:

Supplemental data. Methods The success of endothelium removal was assessed in rat thoracic aorta using acetylcholine (100 nM).

Figure S1 The effect of MRS2179 on ADP-evoked relaxation in the rat thoracic aorta. The effect of MRS2179 on UTPevoked relaxation in the rat thoracic aorta.

Figure S2 The effect of MRS2500 on ADP-evoked relaxation of the porcine mesenteric artery. The effect of MRS2500 on ADP-evoked relaxation of the porcine coronary artery.

Figure S3 The effect of CoA derivatives on ADP-evoked intracellular calcium ion elevations in HEK293 cells. The effect of CoA derivatives on UTP-evoked intracellular calcium ion elevations in HEK293 cells. 